\title{
EXTERNAL DEBT IN BOSNIA AND HERZEGOVINA - AN EMPIRICAL ANALYSIS
}

Jasmina Hurić-Bjelan, Azra Hadžiahmetović

\section{Abstract}

Over the last few decades, many countries in the world have been struggling with high indebtedness. This has been especially emphasized in periods of crisis, and this was not an exception during the last global economic crisis in 2009. The advent of the crisis has further increased the need for borrowing. Increasing indebtedness after the crisis was also characteristic of BiH economy, the country in our research focus, which had an increase of public external debt by over $100 \%$ over the last two decades.

The paper focuses on the external indebtedness of Bosnia and Herzegovina (BiH) over the period 2004-2017. The empirical part relies on dynamic modelling - Vector Autoregression Model, which is used to explore total external indebtedness. The empirical investigation implies that foreign-trade exchange deficits have had the greatest impact on rising indebtedness in $\mathrm{BiH}$, while movements in EURIBOR interest rates have little influence in explaining this variability. The empirical investigation implies that macroeconomic policy in $\mathrm{BiH}$, if it wants to keep the external debt under control over the longer time horizon, does need to focus on deficits in its foreign exchange more. One of inevitable priorities is to work on supporting production based of export from this economy.

Keywords: indebtedness, Bosnia and Herzegovina, dynamic analysis, VAR model

\section{JEL classification: H63, CO1, C49}

\section{INTRODUCTION}

More than two centuries ago, one of the most influential economists in history, Adam Smith (1776, p. 5) wrote that "The progress of the enormous debts which at present oppress, and will in the long-run probably ruin, all the great nations of Europe, has been pretty uniform". This elaboration implies that public debts have always been a challenge and it has never been easy to manage indebtidenes. This comes to the fore even more when crises occur on the horizon, and which happened during the last global economic downturn (2008-2009), and had been the case in number of countries throughouth the world. The negative economic effects of the crisis quickly spilled over into transition countries, including Bosnia and Herzegovina
Jasmina Hurić-Bjelan, $\mathrm{PhD}$

(corresponding author)

Head of Sector for Plan, Analysis and Reporting,

Assistant of Director

Tax Administration of the Federation

of Bosnia and Herzegovina

Sarajevo

E-mail: jasmina.huric-bjelan@fpu.gov.ba

Address: Džinina 40, 71000 Sarajevo, B\&H

Azra Hadžiahmetović, PhD

Professor

School of Economics and Business

University of Sarajevo

E-mail: azra.hadziahmetovic@efsa.unsa.ba 
$(\mathrm{BiH})$. The consequences of the global economic slowdown in $\mathrm{BiH}$ were primarily reflected in the deterioration of its fiscal position.

Due to the currency board system under which the Central Bank of BiH operates, the budget deficit can be financed primarily by borrowing. Consequently, the debt growth without positive developments of other indicators might have negative macroeconomic implications to this economy. However, if the borrowed funds are channelled into investments, this directly migh support growth of tax revenues and export, and debts are easily serviced.

The budget deficit is a key indicator of fiscal policy that has multiple implications for the country's macroeconomic position. In order to finance deficits and service all liabilities, funds that are raised through public revenues or borrowing should be at least partly invested so that the economic growth rates would be higher than the interest rates paid for borrowing in the long run. If borrowed funds are invested in unprofitable projects and current spending, there will be a growing gap between government revenues and expenditures. Expenditures will continue to grow, as will interest rates on borrowed funds. Therefore, if these funds are not invested in capitaly intensive activities, there will be no or little growth of GDP, tax revenues and exports. In the case of $\mathrm{BiH}$, the increase in indebtedness in all the years under the focus has not been accompanied by a expected increase in the key macroeconomic indicators. The growth of import has not been supported by export growth, GDP did not have sufficient increase in these years, and revenues did not have the same tendencies as expenditures. Most of funds based on public external debt were used for spending that did not have a feataure to support sustainable economic growth for the country. Thus, we hypothesise in our paper that the the growth of the external debt of $\mathrm{BiH}$ is mainly caused by the growth of government spending and the deficit in foreign-trade exchange. Moreover, as $\mathrm{BiH}$ currency is firmly linked to Euro, we will investigate if the movement of EURIBOR interest rates is relevant in explaining the variability of external debt. We use standard macroeconomic data in our empirical analysis and VAR - Vector Autoregression Model.

The paper is organized as follows. After introductiory section, we provide relevant literature review, the following section introduces theoretical underpinnings of our investigation, including relevant statistical foundations of the VAR models. Empirical investigation starts with introduction of the sample and data, the empirical modelling and discussion of the obtained results follows, while concluding section closes the paper.

\section{LITERATURE REVIEW}

In parallel with the development of economic knowledge and empirical methodologies, various econometric models were used to concduct diverse debt analyses. These are most often models based on cointegration analysis, error correction model, VAR models, regression models, panel models and others. For example, econometric analysis of fiscal sustainability using the VAR model and cointegration analysis is reported by Neaime (2015). The survey used in this contribution is based on 7 European countries and a time series of selected variables from 1977 to 2003. The author concludes that the fiscal policy of Germany and France is sustainable, while other countries: Greece, Ireland, Italy, Portugal and Spain are not fiscally sustainable.This paper also proposes measures that the European Central Bank should take to accelerate economic growth in European countries and reduce the real interest rate. A research paper by Bohn (2005) which focuses on USA economy, investigates fiscal sustainability and debt analysis. This contributions is also based on the VAR or VECM (Vector Error Correction Model) model, using long-time data for the period from 1792 to 2003 . The results of this investigation reveal a sustainability of US fiscal policy. However, the paper reports that unit root tests are not always reliable for such investigations, but an analysis based on equilibrium-error-correction model can determine the state response function in terms of increasing or decreasing public spending and public revenues in different debt movements.

There are a few contributions from this literature that can be marked as interesting for our research in particular, including: Stiglitz (2000), Braeuninger (2002), Hsing (2003), Fosu (2008), Krtalic and Benazic (2008), Reinhart i Rogoff (2010), Juricic et al. (2012), Saint-Paul (2012) and others, which we shortly discuss below.

Stiglitz (2000) points out that governments borrow to invest and raise the quality of public services, but if external debt rises above a certain limit, then the external and total public debt exert pressure on private investment, reduce the competitiveness of the real economy, and reduce output and wages. Otherwise, Stiglitz advocates caution about the level of indebtedness and the negative effects that high debts can cause.

Braeuninger (2002) analyses the dynamics of budget deficits, public debt and growth using the RomerLucas's endogenous growth model. This autor aruges that after a certain point of public debt-to-GDP ratio, public debt growth lowers economic growth rates. If the debt-to-equity ratio is above the critical level, then capital growth declines continuously, becomes 
negative at some point, and further deteriorates.

Hsing (2003), uses VAR methodology ${ }^{1}$ and investigates the impact of external indebtedness and other macroeconomic variables on Brazil's real product. The authors focuses on period from 1993 to 2002 and uses model based on variables of interest rate, external debt, Brazil's real exchange rate, inflation rate and GDP. He concludes that the growth of external debt would have a negative impact on the real product, that is, it would rise in the medium term and fall with other macroeconomic variables. High interest rates, high external debt-to-GDP ratio, and high inflation in Brazil are detrimental to Brazil's real product.

A paper by the Krtalic and Benazic (2008), with the focus on Croatia, is relevant for our investigation. These authors use the same methodology as Hsing (2003), they establish a VAR econometric model for this neighbouring country, and investigate the effects of high external debt and the selected macroeconomic variables on the Croatian economy. The results of the econometric analysis indicate a negative impact of external debt on macroeconomic developments. The impulse response analysis showes that the increase in gross external debt primarily affects the rise in interest rates and the appreciation of the exchange rate, while it has no significant impact on industrial production.

Another paper focused on Croatian economy is by Jurcic et al. (2012) and it also relies on a VAR model for the empirical analysis of external debt. The aim of this contributions was to investigate the interdependence of the factors that caused the sharp rise in debt, and the results of the analysis imply that current account deficits and budget deficits had the greatest importance in explaining the external debt variability, while the variables of interest rate differential and the real Kuna exchange rate were less important.

We are living in the times when many countries face large debts, but still there is a lack of papers which analyse indebtedness. This is even more problematic for $\mathrm{BiH}$, a country in our focus. There is no empirical research with $\mathrm{BiH}$ case study, while statistical sources relevant for such an investigation are also limited. However, it is possible to find a few reviews and professional papers (e.g. Maric, 2012; Krunic, 2012), while there are no a credible scientific reserch, to our knowledge. One of these contributions is by Krunić (2012) which analyses the current state of BiH's public debt, pointing to the lack of a systematic approach to borrowing. The author also points out to the main challenges and consequences of borrowing

1 Which is different from the Sims's methodology used in this paper, primarily in the relation of the variables in the model and the division into endogenous and exogenous ones. in $\mathrm{BiH}$ and the lack of a consistent borrowing policy. Similarly, Marić (2012) provides a brief analysis of the state and characteristics of public debt (dynamics, maturity, structure, intended use, etc.), as well as a forecast of servicing and consequences of public debt in the context of macroeconomic conditions in $\mathrm{BiH}$. The paper concludes that sustainability, i.e. servicing of public debt in the context of foreign trade deficits, budget deficits and zero rate of economic growth will not be possible without lowering citizens' standards of living (by increasing tax rates, lowering budget expenditures for salaries and social benefits). It is stated that without decisive structural reforms in the public sector and a change in the concept of development that will enable a general economic recovery, $\mathrm{BiH}$ is surely going into a debt crisis $^{2}$. Appart these papers directly focused on indebtideness in $\mathrm{BiH}$, there is also a few research which indirectly touched the issue of public debt in $\mathrm{BiH}$ (e.g. Hadziahmetovic 2011; Efendic and Hadziahmetovic 2015), but a thorough investigation with empirical analysis remains a current gap in knowledge, which motivated our investigation.

\section{THEORETICAL AND STATISTICAL FOUNDATIONS OF THE EXTERNAL DEBT MODELLING}

Vector Autoregression Model - VARs - are used to test general economic assumptions (relationships or causality among variables), but their most common method of application is that they yields the best and most comprehensive results in the dynamic analysis of a group of economic phenomena. The application of VAR methodology to economic research was first proposed by Nobel laureate Christopher Sims (1980). According to Bahovec and Erjavec (2009, p. 365) VAR models are dynamic models of a group of time series and are a generalization of dynamic models defined on the basis of a single equation. The results obtained by analysing VAR models are the basis for understanding and exploring interdependence in a group of economic variables and defining structural economic models.

Juselius (2005) states that the VAR model allows data to speak freely. The key stages in applying the VAR methodology are the specification and estimation of model parameters, the impulse response function, and the decomposition of the variance of the

2 During the research, attempts were made to find more papers that address the indebtedness and fiscal sustainability of $\mathrm{BiH}$, but this was not successful, and this is one of the limitations of the research. 
prediction error.

The general form of a VAR model based on $n$ variables with displacement length $\mathrm{k}$ is: ${ }^{3}$

$Z_{t}=\mu+A_{1} Z_{t-1}+\ldots+A_{k} Z_{t-k}+\psi D_{t}+e_{t}$

where $z_{t}=\left[\begin{array}{c}Z_{1 t} \\ Z_{2 t} \\ \cdot \\ \cdot \\ \cdot \\ Z_{n t}\end{array}\right] \quad$ possibly endogenous variable:

$A_{1}, A_{k}$ are square matrices of autoregressive parameters of order $(n \times n)$,

$D_{t}$ is a vector of non-stochastic exogenous variables with a parameter matrix $\psi$,

The vector $\mathrm{D}_{\mathrm{t}}$ may contain a trend component, binary (dummy) variables to incorporate the impact of different interventions (external shocks) into the model, or it may, for example, contain seasonal components if seasonal influence is present in the variables.

$\mu=\left[\begin{array}{c}\mu_{1} \\ \mu_{2} \\ \cdot \\ \cdot \\ \cdot \\ \mu_{n}\end{array}\right], \quad$ is the vector of constant members

$e_{t}=\left[\begin{array}{c}e_{1 t} \\ e_{2 t} \\ \cdot \\ \cdot \\ \cdot \\ e_{n t}\end{array}\right]:$ is the vector of innovation,

i.e. the $\mathrm{n}$-dimensional vector white noise process with the expected value of zero and the covariance matrix $\Sigma$, where for each $\mathrm{t}$ :

$\mathrm{E}\left(e_{\mathrm{t}}\right)=0$ and $\mathrm{E}\left(e_{\mathrm{t}} e_{\mathrm{s}}^{\prime}\right)=\left\{\begin{array}{l}\sum t=s \\ 0 t \neq s\end{array}\right.$

The VAR model is defined by the variables $X_{t}$ and $Y_{t}$ and the displacement length $k=1$ is:

$X_{t}=b_{10}-b_{11} Y_{t}+c_{11} X_{t-1}+c_{12} Y_{t-1}+\varepsilon_{x t}$

$Y_{t}=b_{20}-b_{21} X_{t}+c_{21} X_{t-1}+c_{22} Y_{t-1}+\varepsilon_{y t}$,

The stationarity of series must be examined before evaluating the VAR model. The estimation of the stationarity of time series is made at the beginning of

3 Retrieved from Bahovec and Erjavec (2009), pp. 339-341. the analysis because in the case of inclusion of nonstationary time series variables into the econometric model a wrong conclusion can be drawn about the relationship between the variables. Thusm, stationarity needs to be checked in the process of application of these models (Bahovec and Erjavec 2009, p. 346-363).

The concept of stationarity is very important in the time series analysis. If the time series is not stationary, the results of the VAR model will not be consistent. A time series is stationary if it does not contain a trend component (the occurrence level does not change with time), if strictly periodic variations are not present in the series, and if its variation is independent of time. Formally, this means that an arbitrarily chosen natural number $n \in \mathrm{N}$ and every displacement $\mathrm{k} \in \mathrm{N}$, $\mathrm{n}$ - the dimensional distribution function satisfies the equation

$\mathrm{Fy}_{1}, \mathrm{y}_{2}, \ldots, \mathrm{yn}_{\mathrm{n}}\left(\mathrm{y}_{1}, \mathrm{y}_{2}, \ldots, \mathrm{yn}_{\mathrm{n}}\right)=$

$\mathrm{Fy} 1+\mathrm{k}, \mathrm{y}_{2}+\mathrm{k}, \ldots, \mathrm{yn}_{\mathrm{n}+\mathrm{k}},\left(\mathrm{y}_{1}, \mathrm{y}_{2}, \ldots ., \mathrm{y}_{\mathrm{n}}\right)^{4}$,

The formal procedure for testing the presence and type of non-stationarity in linear time series models consists of a group of tests knowen as unit root tests.

An innovative analysis representing two sets of phenomena is used to evaluate the VAR model, and this is the term used to denote impulse response function and variance decomposition. The advantage of innovation analysis is a convenient interpretation of the parameters and the ease of drawing conclusions about the dynamics of the variables (Asteriougiles 2006).

In addition, the stability of the VAR model must be evaluated prior to the innovation analysis itself, using the root of the characteristic polynomial in the model. The system is stable if and only if all the variables involved in the model are weakly stationary, that is, if all the roots of the characteristic equation of the polynomial expression by lags are located within the unit root (Mladenović and Nojković 2012).

The impulse response function is used as the "dynamic" response of each endogenous variable to a unit "shock" in the system of variables, more precisely the $i$-th variable in the innovation process at time $t\left(e_{i t}\right)$. The "shock", i.e. the change in a particular variable not only directly affects that variable, but through the dynamic (lag) structure of the VAR model, the impact of the change also reflects on all endogenous system variables.

In the case where innovations $e_{i t}$ are uncorrelated in time $t$, interpretation of the coefficients of the impulse response function is simple. For example, if a 
unit "shock" occurred in the $i$-th variable and at the time $t\left(e_{i t}\right)$ the impulse response function coefficients are interpreted as changes in all system variables caused by that unit "shock".

However, innovations $e_{i t}$ are most commonly correlated and contain a common component that can be attributed to a particular variable. Then the interpretation of the coefficient of the impulse response function is complex and often impossible. In such cases, in order to interpret the coefficients of the impulse response function coherently, innovations are usually transformed so that they "become" uncorrelated. Namely, it is necessary to find an adequate transformation (matrix $P$ ) such that the vector of transformed innovations $_{V t}=P e_{t}$ has an expected value of zero and a covariance matrix $D$, where $D$ is a diagonal matrix. The choice of the appropriate transformation is thus reduced to the problem of diagonalization of the covariance matrix of the innovation process (Bahovec and Erjavec 2009, p. 346).

The impulse response function shows the effect of a unit increase in the "shock" of one endogenous variable on the other variables of the VAR model. In this research, it will be used to show the response of external debt to changes in key variables in the model.

Decomposition of VarianCe (DVC) is used to analyse the dynamics of the VAR model. In this way, the relationships of changes in one variable resulting from the shock in that variable are analysed, as well as changes that occurred under the influence of shock in all other variables of the system. The shock in $i$-th variable in the system causes changes in that variable, but it is also passed on to other variables because of the dynamic structure of the vector autoregressive models.

The decomposition of variance provides information for the selected forecast horizon about the relative importance of each of the random shocks in the effects of all variables in the VAR model. The source of the forecast error is the variation of current and future values of innovation (Jovičić and DragutinovićMitrović 2011, p. 214).

Namely, the vector process $Z_{t}$ can be written:

$\mathrm{Z}_{t}=\beta D_{t}+\sum_{i=0}^{\infty} \Psi_{\Delta} e_{t-\varepsilon}$

$\beta D_{t}$ is a deterministic part of the stochastic process $Z t$,

$\{e t\}$ is $n$ - a dimensional innovation process (with an expected value of zero and a covariance matrix $\Sigma$ ),

$\psi_{0}$ is a unit matrix of order $n$, and $\psi_{s}$ are square matrices of coefficients of order $n$.

\section{SAMPLE AND THE DATA}

The VAR model that we estimate is based on the following variables: external debt, fiscal balance, foreign trade balance, total lending activity of banks in $\mathrm{BiH}$ and EURIBOR interest rates.

The selection of this methodology and the selection of variables can be most closely related to the methodology used by Jurcic et al. (2012), as well as other contributions already discussed. However, we provide economic arguments for integration of these variables into the final model.

The external debt variable is determined by all other selected variables introduced in our system. The value of the external debt variable implies the total value of BiH's public external debt and BiH's private external debt. BiH's total public external debt implies BiH's debt to international creditors. Unlike the previous analysis of the external public debt of $\mathrm{BiH}$, the private external debt of $\mathrm{BiH}$ is for the first time included in the dynamic analysis of external indebtedness, which includes the debt of companies and of the population in $\mathrm{BiH}$. No institution in $\mathrm{BiH}$ has this data on a quarterly basis and for that reason the annual external debt data has been taken from the World Bank ${ }^{5}$. From US Dollars, at the rate valid on 31/12/2017, they were converted to BAM and reduced to the quarterly level by the least squares method in Eviews 10. A similar interpolation methodology was made in the article Čolaković, Hlivnjak (2007).

In this way, as for all other selected time series used, 56 quarterly units were obtained. The Chow-lin method of interpolation of annual into quarterly data is used. Chow and Lin $(1971,1976)$ use a simple procedure to interpolate or estimate a series of data based on the same series with a different frequency. This method uses the movement of one variable to move the other and its results depend on the movement on the other variable (proxy variable). For the purposes of this research, the movement of the external debt variable with the lending activity (corporate and retail) movements was taken into account. Data on lending activity were taken from the web site of the Central Bank of BiH.

The Chow-Lin method can be applied to time series, generally using one (univariate case) or multiple indicator series (multivariate case). It is assumed that these series of indicators should be socio-economic variables that are considered to act as a target variable. In the absence of such variables, time functions, as suggested by Chow and Lin (1976), can be used.

5 https://data.worldbank.org/indicator/DT.DOD.DECT.CD?end=2 $\underline{017 \& \text { start }=1970 \& \text { view }=\text { chart\&year low desc=false }}$ 
Fiscal balance variable ${ }^{6}$ i.e. variables of government revenues and government expenditures, respectively, are the variables that mainly have the largest influence on the changes of indebtedness. Growth in government expenditures that is not accompanied by GDP growth and revenue growth leads to increased borrowing needs, while government revenue growth as a result of increased economic activity and GDP reduces external debt. These two variables, as well as the fiscal balance variable, are used in most of the papers discussed in the previous sections, and in particular in papers based on VAR methodology, such as Bohn (2005), Neaime (2015) and Jurcic et al. (2012). In the study of Krznar (2002), who uses cointegration methods to analyse fiscal sustainability, there are two key variables: the movement of government revenues and expenditures. In addition, these variables are also used by Hamilton and Flavin (1986), Wilox (1989), Gregory and Hansen (1996), Giavazzi (2010), who rely on the intertemporal budget constraint approach to assess fiscal policy sustainability.

The foreign trade balance variable represents the difference between the variables of exports and imports of goods and services, which are macroeconomic variables that are usually related to external debt. Higher growth in external debt relative to exports leads to problems in servicing external debt liabilities, since exports are one of the main sources of generation of revenues for debt repayment. In a situation where the export growth rate is higher than the external debt growth rate, the debt repayment ability is improved. These variables, that is, their difference, are also used in the paper of Jurcic et al. (2012), but also in most of the discussed empirical papers, which are based on standard statistical indicators, including here Kersan-Škabić, Mihovilovicć (2008), Galinec (2007) and Jošić (2008).

The variable of total lending activity of banks in $\mathrm{BiH}$ was selected to be part of the model because the movement of lending activity is of paramount importance for all other macroeconomic developments. Given that the economic movement directly depends on the movement of total lending activity in a country, and in turn affects the movement of debt, this variable will also be included in the VAR model. In this way, it is intended to assess what reflections on the indebtedness of $\mathrm{BiH}$ the decline or growth of loans will have over the observed period. The variable of total credit activity of banks in $\mathrm{BiH}$ is used in the research of Novak (2008).

6 The fiscal balance variable represents the difference between the variables of government (consolidated) revenues and expenditures and the net acquisition of financial assets.
The variable of the EURIBOR interest rate was taken for the analysis due to the fact that the rise in interest rates in the money market directly increases the external debt and liabilities that have to be serviced. In the event of a fall in interest rates, the situation should be reversed. This variable is included in the model because over $50 \%$ of BiH's external debt is denominated in Euro and the rest in SDR ${ }^{7}$, US dollars or other currencies. The use of the interest rate variable is very common and is present in most of the research that we rely on the papers Hsing (2003), Bohn (2005), Krtalić and Benazić (2008) and Novak (2008).

All variables except the EURIBOR interest rate variable are expressed in millions of BAM, while the value of the interest rate variable is expressed as a percentage.

It is important to mention that some of macroeconomics variables used in the existing empirical papers cannot be included for the research conducted on $\mathrm{BiH}$. These are, for example, variables in the field of monetary policy, such as the exchange rate. This is due to the currency board system in $\mathrm{BiH}$ or even the public debt variable that could not even be used in the case of this research, since there is insufficient data available for research and methodology that we use.

The time series of data which we use covers the period 2004-2017. The data which are taken for analysis is quarterly and the series will contain 56 time units overal. Regarding the methodology use, this research relies on the Sims's VAR model, its general form (General unrestricted VAR), developed by Sims (1980, p. 1-48), which has no restrictions on the model parameters and in which all variables are equally represented. This meens that there is no division into endogenous and exogenous variables. The variables included in the analysis are denoted as the following: $E D$ - external debt; $F B$ - fiscal balance, $B T$ - foreign trade balance, $T C A B H$ - total lending activity in $\mathrm{BiH}$, INTEURIBOR - EURIBOR interest rates.

In order to analyse the impact of the selected variables on the external debt variable, a VAR model will be estimated following the standard procedure nicely introduced by Bahovec and Erjavec (2009). The results obtained from the VAR model will be the basis for exploring interdependence in a set of selected economic variables. The source of data is the official website of the Central Bank of $\mathrm{BiH}$, the BiH Agency for Statistics (for data relating to $\mathrm{BiH}$ ) and the European Central Bank (for data on EURIBOR).

7 SDR (Special Drawing Right), a unit of account used by the IMF, the World Bank and several other international financial institutions. It consists of a basket of currencies made up of (US dollar, euro, Japanese yen and British pound). 
Following a standard empirical procedure, we start with the ADF test before analysing the model itself. Unit root tests for all variables individually ( $E D, F B, B T$, $T C A B H$, and INTEURIBOR) were performed.

The ED variable is stationary in levels and the the null hypothesis of non-stationarity can not be accepted. The FB variable is $\mathrm{nn} /$ stationary in levels, but it is stationary in the first differences. The ADF test showes that the BT variable is stationary at levels, the EURIBOR interest rate variable is not stationary in levels but it is stationary in the first differences.

VAR analysis always is done before innovation analysis and as a rule, the system is stable only if all the variables involved in the model are weakly stationary, that is, if all the roots of the characteristic equation of the polynomial expression by lags are located within the unit root (Bahovec and Erjavec 2009, p. 367). The stability of the model is a prerequisite for further testing, so we first check that the VAR model is stable. This will be done through the specification of the model introduced as follows.

$$
Z_{t}=\left(E D_{t}, \Delta F B_{t}, B T_{t}, \Delta T C A B H_{t}, \Delta I N T E U R I B O R_{t}\right)^{\prime}
$$

The estimated VAR model has five variables (ED, FB, $B T, T C A B H$, and INTEURIBOR).

We find that the VAR model is well defined and the $\beta$ coefficient, standard error and t-statistic are presented for each variable. For example, the coefficient for $D(E D)(-1)$ in $D(F B)$ is negative and is 0.01 , the standard error is 0.14 , and the corresponding t-statistic is -0.12 .

The estimated equation (change) in external debt can be written:

$\Delta E D=-928.6356+1.780280 \Delta E D_{t-1}+0.043273 \Delta F B_{t-1}$ $+0.546808 B T_{t-1}-0.374226 \Delta T C A B H_{t-1}$

$-70.22898 \Delta I N T E U R I B O R_{t-1}$

In addition to this model stability assessment, Table 1 and Figure 1 show the stability analysis of the VAR model using the root of AR characteristic polynomial.

The VAR model is stable if the modules of all roots of a characteristic polynomial are greater than one, that is, they are located outside the unit circle (according to Euclidean norm) or if they are all smaller than one (Jurčić et al. 2012, p. 280). If this condition is not satisfied, the results of the econometric analysis are not appropriate.
Table 1. Stability of VAR model - roots of characteristic polynomial

\begin{tabular}{|c|c|}
\hline \multicolumn{2}{|c|}{ The roots of a characteristic polynomial } \\
\hline \multicolumn{2}{|c|}{ Endogenous variables: } \\
ED D(FB) BT D(TCABH) D(INTEURIBOR) \\
\hline \multicolumn{2}{|c|}{ Lag specifications: 12} \\
\hline Root & Modulus \\
\hline 0.903911 & 0.903911 \\
\hline$-0.061449-0.730484 i$ & 0.733064 \\
\hline$-0.061449+0.730484 i$ & 0.733064 \\
\hline $0.660836-0.231138 i$ & 0.700092 \\
\hline $0.660836+0.231138 i$ & 0.700092 \\
\hline-0.605419 & 0.605419 \\
\hline 0.585765 & 0.585765 \\
\hline-0.310768 & 0.310768 \\
\hline$-0.050653-0.244898 i$ & 0.250082 \\
\hline$-0.050653+0.244898 i$ & 0.250082 \\
\hline
\end{tabular}

Source: The author's calculation

The results of the analysis show that no root is outside the circle, that is, the VAR model satisfies the stability condition. All modules in the table have values less than one, i.e. from 0.90 to 0.25 from largest to smallest.

In addition, when the roots of the polynomial are inside the unit circle, it is concluded that the VAR model is stable, as it can be seen from the figure below.

Figure 1. Unit circle with polynomial roots Inverse Roots of AR Characteristic Polynomial

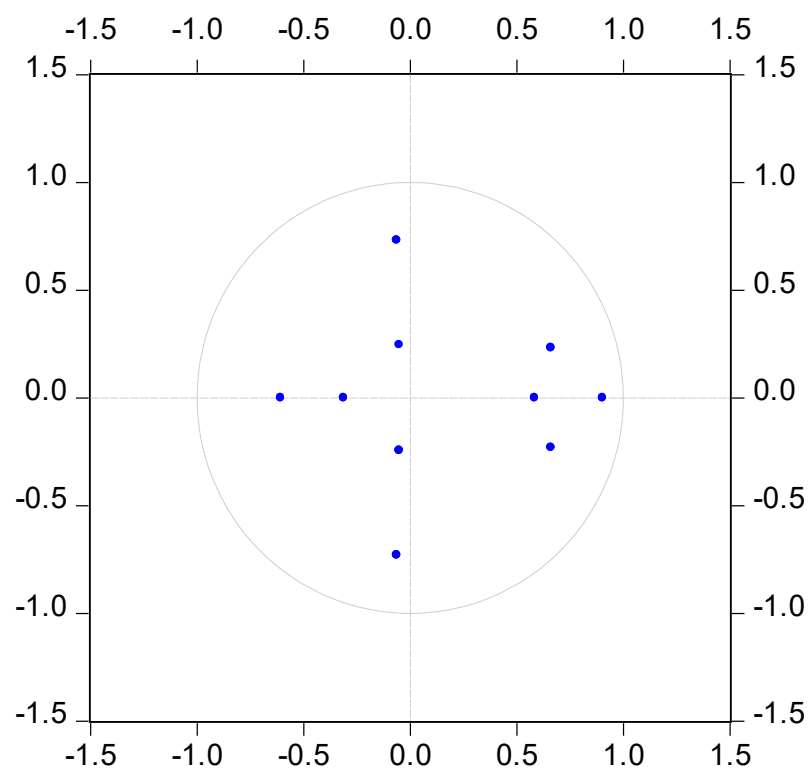

Source: The author's calculation 
The results of the analysis of the unit circle with polynomial roots show that none of the roots, ten of them as confirmed by the model, is outside the circle, that is, the VAR model satisfies the stability condition. The number of displacements in the model is 13 and was determined based on Akaike and Schwarz information criteria. The validity of the selected number of displacements is confirmed by the diagnostic tests of autocorrelation and the stability tests of the evaluated models.

LM test of the autocorrelation of residuals in the VAR model confirmed that the residuals were not autocorrelated. In addition, all residuals in the model are stochastic, which is very important and necessary, and this is confirmed by the graphical representation of the residuals (Figure 2).

As relevant model diagnostics are satisfactory our next step in the analysis is to determine causality, followed by decomposition of variance and presentation of impulse response function, which represents the most important part of the research that tests the selected hypotheses.

The previous analyses have proved that the model is stable and satisfactory. Thereafter, Granger's causality test was conducted, which showed that there was a significant causal relationship in the direction of the foreign trade balance towards the external debt variable, i.e. the foreign trade balance variable's ability to predict the dynamics of the external debt variable ( $p$ - value is 0.0023). Of all the other variables, the fiscal balance has the largest influence in predicting the foreign trade balance variable, where the F-test value is 18.51 , while the $p$-value is 0.0000 . With the F-test value of 10.34 and a $p$-value of 0.000 , a causal relationship exists in the direction of the total lending activity variable towards the foreign trade balance variable.

Figure 2. VAR model residuals - LM autocorrelation test

\section{VAR Residuals}

ED Residuals

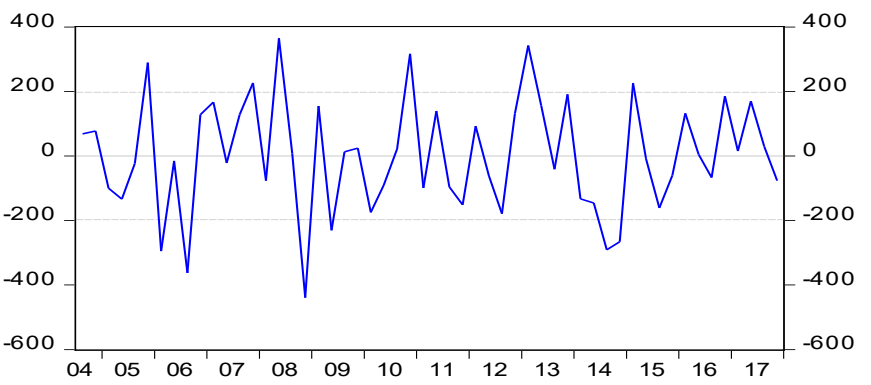

BT Residuals

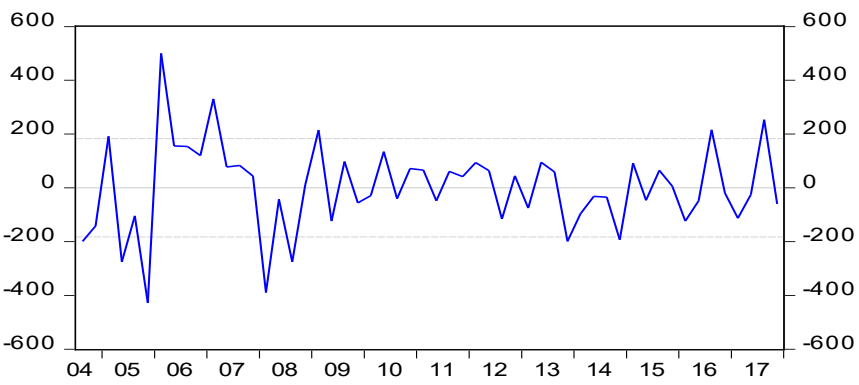

INTEURIBOR Residuals

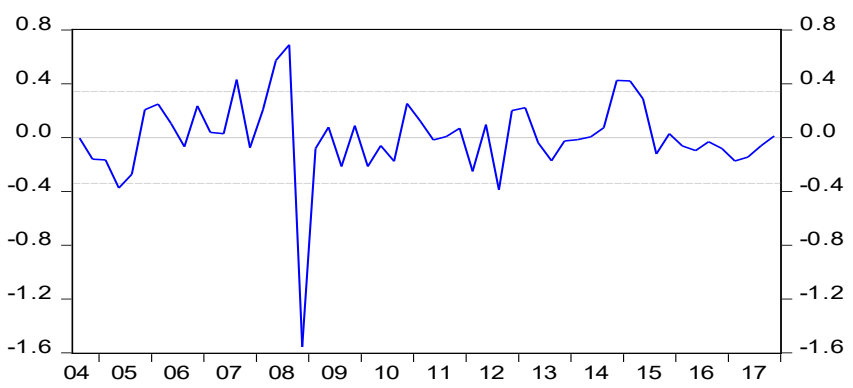

Source: The author's calculation
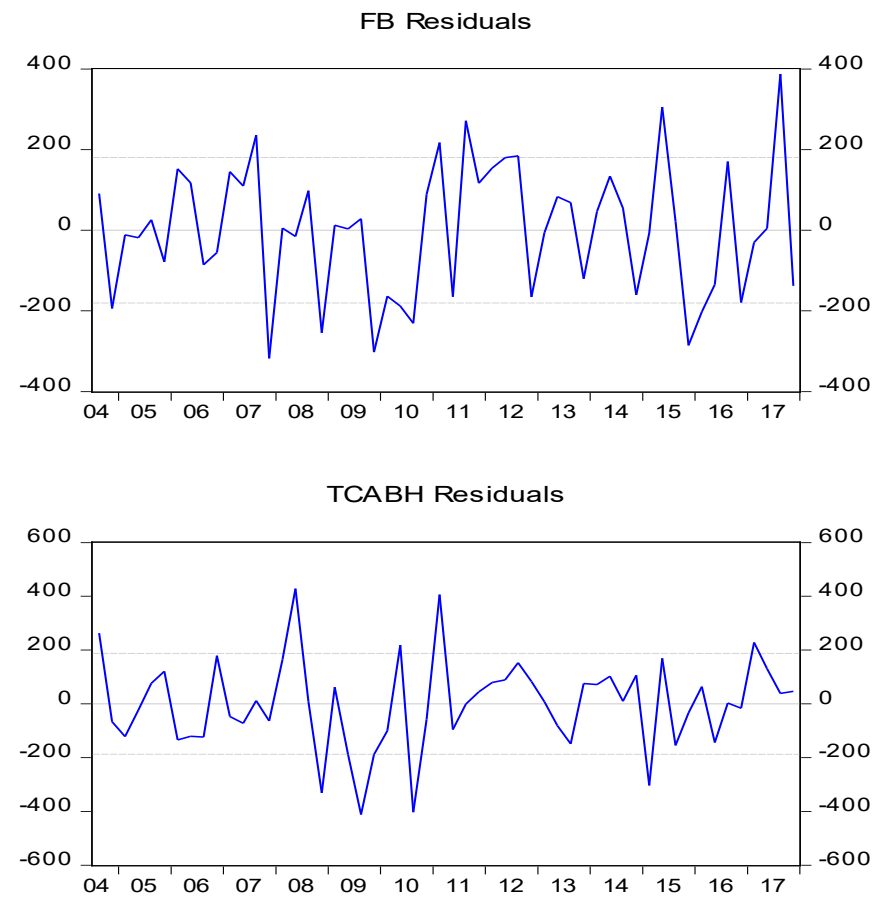
Likewise, according to the results of the F-test of 7.08 and the $p$-value of 0.0020 , the external debt variable causes the total lending activity variable.

\subsection{Variance decomposition and impulse response function}

Analysis of the variance decomposition aims to identify the most important determinants of variability of endogenous variables from the model. The results obtained by the variance decomposition show the importance of individual variables in explaining the variability of external debt. Cholesky's decomposition and prognostic horizon $\mathrm{t}=10$ were used. Variance decomposition was performed with the following order of variables: ED, FB, BT, TCABH, INTEURIBOR As the subject of interest here is external debt, we will analyse in more detail the decomposition of the variance of this variable for 10 quarters (Table 2).

The variance decomposition estimates suggests that the largest fluctuations in the external debt (ED) variable are owed to shocks in the variable itself $(100 \%)$. The external debt variable itself in the first quarter $(\mathrm{k}=1)$ explains $100 \%$ of the variance of its forecasting error. After the 10th quarter, this percentage drops to $80 \%$. Although a preview up to 10 quarters is reported here, according to a printout that we obtain, it remains at this level until the end of 56th quarter.

It is common for the first variable in the order to explain most of its variability, while the variable that does not affect the other variables is placed at the end of the order. In the first quarter, no variable is significant in explaining the variation in the external debt variable, but in the second quarter, the BT (foreign trade balance) variable has the greatest significance in explaining the variation of the ED (external debt) variable, i.e. $7.5 \%$. This percentage increases further and in the 10th quarter stands at $18.3 \%$.

After this variable in the second quarter, the variable of total lending activity has the greatest importance in explaining the variation of external debt (2.55\%). While the importance of the foreign trade balance variable is increasing according to the 10th quarter, the total credit activity is decreasing with the variable and stands at $1.38 \%$ in the 10th quarter. For the variables of fiscal balance and EURIBOR interest rates in this period, relative to the initial quarters, significance is decreasing ( $0.09 \%$ and $0.21 \%$ respectively).

According to the results obtained, the variable foreign trade balance in the first quarters has the greatest significance in the variation of the external debt, and only then the variable of total lending activity and finally the variables of EURIBOR interest rate and the fiscal balance. This situation is at the beginning of the observed period of time, i.e. in the first quarters, but going forward, the situation is changing, i.e. the significance of the foreign trade balance variable continues to increase, and the significance of the variable of total lending activity is decreasing. The variables of fiscal balance and EURIBOR interest rates also have declining significance towards the 10th quarter.

This means that the greatest significance in the variability of the external debt variable can be attributed to the different movements of the foreign trade balance variable, i.e. the foreign-trade exchange deficit. The significance of the fiscal balance variable moderately declines and at the end of the 10th quarter it is smaller than both the EURIBOR interest rate variable and the total lending activity variable. Thus, the fiscal balance variable and rising government spending did not dominantly cause the growth of total external debt in the observed time period, but this was rather contributed by the current situation in the

Table 2. Variance decomposition for variable ED

\begin{tabular}{|c|c|c|c|c|c|c|}
\hline Period & S.E. & ED & D(FB) & BT & D(TCABH) & D(INTEURIBOR) \\
\hline 1 & 216.1568 & 100.0000 & 0.000000 & 0.000000 & 0.000000 & 0.000000 \\
\hline 2 & 430.8517 & 88.62330 & 1.044545 & 7.527776 & 2.550338 & 0.254040 \\
\hline 3 & 637.9472 & 86.05857 & 0.528994 & 11.27696 & 1.910876 & 0.224606 \\
\hline 4 & 834.0465 & 84.44641 & 0.328858 & 13.09537 & 1.996627 & 0.132733 \\
\hline 5 & 1007.382 & 83.81097 & 0.226215 & 14.14634 & 1.711360 & 0.105116 \\
\hline 6 & 1163.423 & 82.89420 & 0.177875 & 15.25589 & 1.567001 & 0.105031 \\
\hline 7 & 1301.275 & 82.05049 & 0.142250 & 16.22437 & 1.455545 & 0.127346 \\
\hline 8 & 1419.999 & 81.26790 & 0.119666 & 17.03544 & 1.416827 & 0.160166 \\
\hline 9 & 1519.308 & 80.59561 & 0.104544 & 17.72051 & 1.389053 & 0.190277 \\
\hline 10 & 1601.667 & 79.99429 & 0.094069 & 18.31653 & 1.382936 & 0.212174 \\
\hline \multicolumn{7}{|c|}{ Order of variables in Cholesky's factorization: ED FB BT TCABH INTEURIBOR } \\
\hline
\end{tabular}

Source: The author's calculation 
foreign-trade exchange movement, i.e. the long-term foreign-trade exchange deficits.

Considering that over the longer term the importance of the total lending activity variable dominates, we conclude that this variable has a greater importance than the EURIBOR interest rate variable (the significance of which is slightly less dominant only at the beginning), and the fiscal balance variable certainly has a declining importance in the variation of movements in the external debt variable. However, it is less importante than the EURIBOR interest rate variable and thus we cannot accept part of Hypothesis 1, which states that the biggest reason for the growth in external indebtedness (in addition to the foreign-trade exchange deficit) is excessive government spending or insufficient government revenue growth.

Based on the estimated parameters of the VAR model, in the next stage, the cumulative responses of the variables to the shocks (impulses) of all variables from one standard deviation were calculated. The results of the effect of unit shocks of the selected variables on the external debt variable are reported in the table below (Table 3).

The impulse response function shows impact of unit shocks in all variables (FB, BT, TCABH, INTEURIBOR) on the ED variable. The first column shows the effect of a unit "shock" (an increase by one standard deviation) in the ED variable on the ED. The shock of one standard deviation in the ED is $216 \%$.

After one period (period 2 in printout) the ED is $343 \%$ units above the average level, i.e. an increase of $343 \%$. After 6 th quarter (period 6 in printout), ED is as high as $521 \%$ above the average level. However, after this quarter it starts to decrease, but it is still above the average level in the 9th and 10th quarters (by 471 and $438 \%$, respectively).

The second column gives the effect of the unit "shock" in the fiscal balance variable on the external debt variable. There is no impact in the first quarter, and already in the second quarter the FB variable is above the average level by $44 \%$. Going further, it is already below the average level by over $14 \%$ in the third quarter. After this decline, in all subsequent quarters it continues to grow until the 7th quarter, when it falls and grows alternately and in the 10th quarter is $0.04 \%$ below the average level of the external debt variable.

The third part of the impulse response result refers to the impact of a unit "shock" in the foreign trade balance variable on the variable external debt. There is no impact in the first quarter, while in the second quarter the BT variable is above the average level by $118 \%$. Subsequently, it continues to grow until the 9th quarter, when its growth above the average level is slightly decreasing compared to the previous quarter and reaches $256 \%$ above the average level of the external debt variable. At the end of the 10th quarter, the foreign trade balance variable is $247 \%$ above the average level of the external debt variable.

According to Table 3, it is evident that the impact of the unit "shock" in the total lending activity variable on the external debt variable in the first quarter is unaffected, and already in the second quarter the TCABH variable is below the average level by over $68 \%$. Going further, in the third quarter it is down by about $55 \%$. This situation varies from quarter to quarter, but in each selected quarter, it is below the average level of the external debt variable. It is down by $58 \%$ in the 10th quarter.

The fifth column shows the impact of the EURIBOR interest rate variable on the external debt variable. In the first quarter for the variable $\mathrm{FB}$, there is no effect, as in all other variables, and already in the second quarter, the FB variable is below the average level by over $21 \%$. It is falling until 4 th quarter and then

Table 3. Impulse Response Function - Impact of Unit Shocks in Variables D(FB), BT, D(TCABH), D(INTEURIBOR) on ED variable

\begin{tabular}{|c|c|c|c|c|c|}
\hline Period & ED & $\mathrm{D}(\mathrm{FB})$ & $\mathrm{B}$ & $\mathrm{D}(\mathrm{TCABH})$ & D(INTEURIBOR) \\
\hline 1 & 216.1568 & 0.000000 & 0.000000 & 0.000000 & 0.000000 \\
\hline 2 & 343.2062 & 44.03432 & 118.2119 & -68.80606 & -21.71595 \\
\hline 3 & 430.9571 & -14.62404 & 178.6632 & -55.15926 & -21.03596 \\
\hline 4 & 487.0311 & 11.60881 & 212.6058 & -78.18178 & -3.040351 \\
\hline 5 & 512.9253 & 2.833427 & 229.0502 & -58.97463 & 11.97494 \\
\hline 6 & 521.0438 & 10.58087 & 250.8719 & -61.99170 & 18.83901 \\
\hline 7 & 517.0664 & -1.051209 & 261.2154 & -58.62423 & 27.10590 \\
\hline 8 & 499.3081 & 2.051004 & 262.2440 & -62.62479 & 32.75979 \\
\hline 9 & 470.8545 & 0.498246 & 256.0084 & -59.11531 & 34.09665 \\
\hline 10 & 437.8763 & -0.041215 & 246.6544 & -58.42501 & 32.41642 \\
\hline \multicolumn{7}{|c|}{ Order of variables in Cholesky's factorization: ED D(FB) BT D(TCABH) D(INTEURIBOR) } \\
\hline
\end{tabular}

Source: The author's calculation 
continues to grow and at the end of 10th quarter the variable INTEURIBOR is $32 \%$ above the average level of the external debt variable.

The results obtained by the variance decomposition were confirmed in the same way by the impulse response function. At the end of the tenth quarter, the foreign trade balance variable was the highest above the average level of the external debt variable (almost
$247 \%)$, followed by the EURIBOR interest rate variable with $32 \%$.

Figure 3 shows the impulse responses of external debt to changes in the variables of fiscal balance, foreign trade balance, total lending activity and EURIBOR interest rates by one standard deviation over a period of 56 quarters.

Figure 3. Impulse responses of external debt to changes in other variables

\section{Response to Cholesky One S.D. (d.f. adjusted) Innovations}
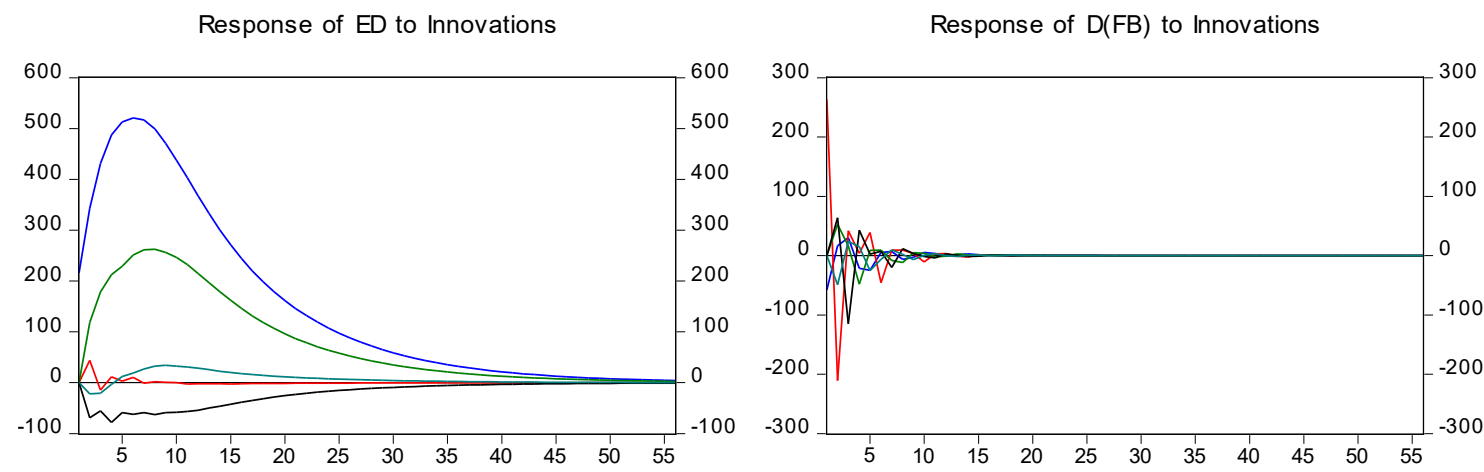

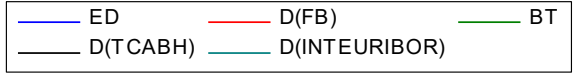

Response of BT to Innovations
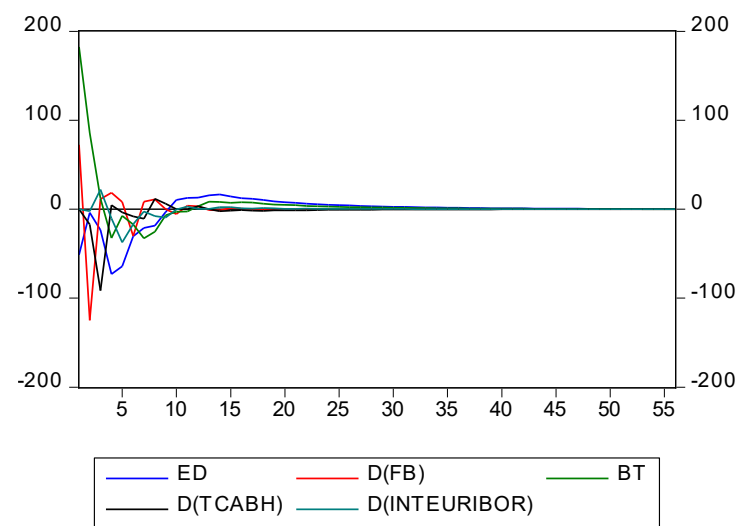

Response of $\mathrm{D}$ (INTEURIBOR) to Innovations
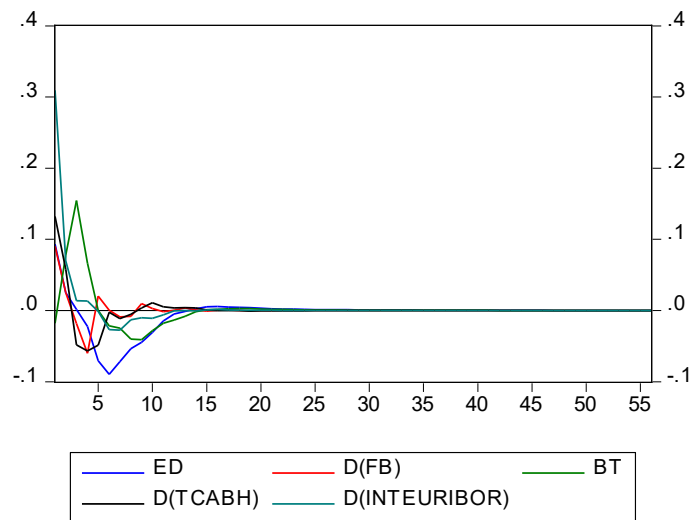

Source: The author's calculation

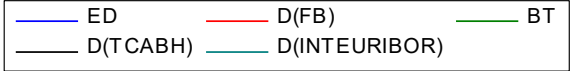

Response of $\mathrm{D}(\mathrm{TCABH})$ to Innovations
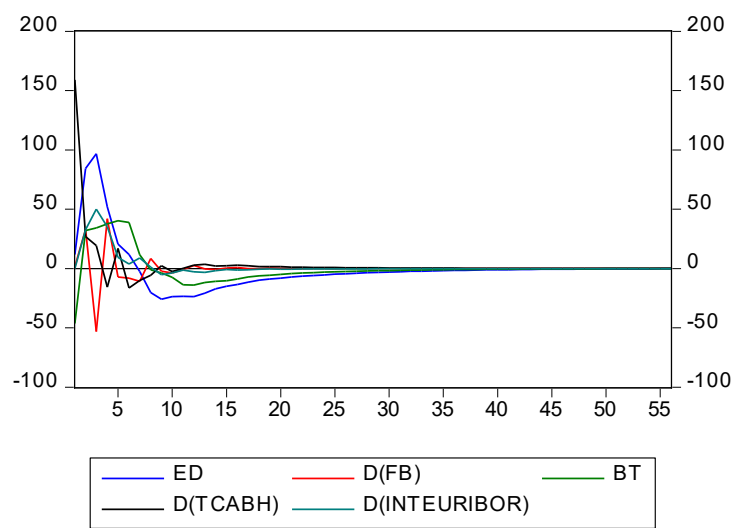
Based on the estimated parameters of the VAR model, the cumulative responses of the variables to the shocks (impulses) of all variables were calculated. The first figure is relevant to the analysis of external debt, where it is observed that an increase in the foreign trade balance by one standard deviation would lead to a slight increase in external debt during the first six quarters, after which the external debt would slowly begin to decline and the initial shock effect would disappear between 25th and 35th quarters. Increasing total lending activity and Euribor interest rates would not have such an effect.

\section{CONCLUSION}

This study provides an empirical assessment of the impacts of key macroeconomic variables on external indebtedness, as well as to examine their links and dynamics with the use of the VAR methodology. The paper analyses long-standing negative tendencies in the trends of the indebtedness of $\mathrm{BiH}$, disproportionate growth of expenditures and revenues, and the existence of high budget deficits of $\mathrm{BiH}$.

Our research indicates that the growth of $\mathrm{BiH}$ external debt is mainly caused by the deficit in foreign trade-exchange. Thus, the greatest importance in the variability of the external debt variable can be attributed to the behavour of the foreign trade balance, hence, to the long-lasting and very high level of this deficit. A high level of foreign trade deficit in $\mathrm{BiH}$ is a persistent phenomenon over the last two decades (starting from post-war period), which signifies importance of this macroeconomic problem to policy makers of this country. Simply, if policy makers want to achieve long-run sustainability of the external debt, hence, external macroeconomic stability, there is a need to tackle the challenge of high foreign trade deficit immdeidatelly. This can be done in several ways, but considering specifics of $\mathrm{BiH}$ environment with currency Board arrangement (Begovic et al. 2016), huge diaspora remittances that are likely to shrink in the future (Efendic at al. 2014; Efendic 2016), high emigrations intentions in the country and the region (Zbinden et al. 2016), a higher export and more substitutions of import is necessary for the more stable macroeconomic environment of this country.

In addition, due to the debt structure and the significant participation of private debt, the tendencies of which were caused by movements in the EURIBOR interest rate, it has been proven that EURIBOR interest rates, after the foreign trade balance variable, have the greatest importance in explaining the variation in the forecasting error of $\mathrm{BiH}$ external debt. This result is not surprising, considering the importance of Euro for $\mathrm{BiH}$ economy and future EU integrations (Hadziahmetovic 2011).

Finaly, some limitations of this research should be mentioned, starting with the challenge linked to the lack of data necessary to conduct deper investigation of the external debt. This is due to the fact that a large number of macroeconomic data for $\mathrm{BiH}$ are available from 2004, and mainly on annual basis, which is limitation that cannot be tackled. In addition, from a macroeconomic point of view, it would be interesting to investigate also a dynamic analysis of total public debt, not just external, but currently this is not feasible given the available data for $\mathrm{BiH}$, which might change in the future.

\section{REFERENCES}

Asteriou, D. 2006. Applied Econometrics: A Modern Approach using EViews and Microfit. Palgrave Macmillan. Hampshire.

Bahovec, V., Erjavec, N. 2009. Introduction to Econometric Analysis. Element. Zagreb.

Begovic, S., Adnett, N. and Pugh, G. 2016. An investigation into the credibility of currency board arrangements in Bosnia and Herzegovina and Bulgaria. Journal of Comparative Economics 44 (3): 787-799.

Bohn, H. 2005. The Sustainability of Fiscal Policy in the United States. CESifo Discussion Paper 1446.

Bosnia and Herzegovina Ministry of Finance and Treasury. 2014. Information on the state of public debt of Bosnia and Herzegovina as at 31.12.2013. and information for the period 2009-2013.

Braeuninger, M. 2002. The Budget Deficit. Public Debt and Endogenous Growth. Journal of Public Economic Theory. Association for Public Economic Theory, vol. 7(5), pages 827-840.

Central Bank of BiH. 2015. Annual reports. (online) available at: www.cbbh.ba (access from 1 January to 8 April 2015)

Chow, G., Lin, A. 1976. Best linear unbiased estimation of missing observations in an economic time series. Journal of the American Statistical Association 71: 719-721.

Chow, G., Lin, A.1971. Best Linear Unbiased Interpolation. Distribution and Extrapolation of Time Series by Related Series. The Review of Economics and Statistics. Vol. 53. No.4. pp. 372- 375.

Čolaković, B. Hlivnjak, S. 2007. Estimate of quarterly GDP for the period 2000-2006, available at: http://cbbh.ba/files/ specijalne_teme_istrazivanja/STI_04_en.pdf

Efendic, A. 2016. Emigration intentions in a post-conflict environment: evidence from Bosnia and Herzegovina. Post-Communist Economies 28 (2): 335-352. 
Efendic, A. and Hadziahmetovic, A. 2015. Post-war economic transition in Bosnia and Herzegovina - a challenging transformation. In State-Building and democratization in Bosnia and Herzegovina, edited by S. Keil and V. Perry, 109-130. Routledge. Oxon and New York.

Efendic, A., Babic, B. and Rebmann, A. 2014. Diaspora and Development - Bosnia and Herzegovina. Embassy of Switzerland in Bosnia and Herzegovina. Sarajevo.

Engle, R. F. i Granger, C. W. J. 1987. Co-Integration and Error Correction: Representation, Estimation, and Testing. Econometrica. Vol. 55, No. 2. pp. 251-276.

Eurostat newsrelease euroindicators. (online) 60/2011 April 2011. available at: www.ec.europa.eu. (access on 24 March 2015).

Fosu, A.K. 2008. Implications of the External Debt-servicing Constraint for Public Health Expenditure in Sub-Saharan Africa. Oxford Developmental Studies. Vol. 36. No. 4.

Galinec, D. 2007. Financing and limits of sustainability of the current account deficit of the Republic of Croatia, available at: https://tkojetko.irb.hr/documents/12431_326. pdf. (access on 1 December 2014).

Giavazzi F. 2010. Fiscal and monetary policies in the crisis: The exit stage. Bellagio Group meeting. Stockholm. Available at: www.unibocconi.it. (access on 5 August 2013).

Gregory, A. W., Hansen, B. C.1996. Residual-based tests for cointegration in models with regime shift. Journal of Econometrics. 70. 99-126.

Hadziahmetovic, A. 2011. Ekonomija Evropske Unije. University Press, Sarajevo.

Hamilton, J., Flavin, M. A. 1986. On the Limitation of Government Borrowing: A Framework for Empirical testing. American Economic Review. 76 (September). 808-819.

Hsing, Y. 2003. Impacts of external debt and other macroeconomic policies on output in Brazil: A VAR approach, Revista de Análisis Económico, Vol. 18, NO. 2

Jošić H. 2008. Comparative analysis of indicators of external indebtedness of the Republic of Croatia and transition countries. Proceedings of the EFZG, 1. 179.-191.

Jovičić M., Dragutinovć-Mitrović R. 2011. Econometrics metods and models. Beograd: CIDEF.

Jurčić, Lj. Jošić, H., Jošić M. 2012. Empirical analysis of external debt of Croatia: Approch using the VAR model. Economics Rewiev. 63 (5-6). 265-290.
Kersan-Škabić, I., Mihovilović G. 2006. Comparative analysis of debt of Croatian and countries of Middle and East Europe. Economics research. Vol.19 No 1.

Krtalić, S., Benazić, M. 2008. External debt of Croatia - where is exit?. Economy, nr.12. Zagreb.

Krunić, M. 2012. Current problems and challenges of public debt in $\mathrm{BiH}$. The Proceedings of the Faculty of Economics in East Sarajevo - Journal of Economics and Business. $\mathrm{Nr}$ 6. 161 - 176.

Krznar, I., 2002. Analysis of the sustainability of fiscal policy in Croatia. Financial Theory and Practice 26 (4). 813-835.

Marić, Ž. 2012. Public debt and debt crisis (example of Bosnia and Herzegovina). Oeconomica Jadertina 2/2012.

Mihaljek, D. 2003. Analysis of the sustainability of Croatia's public and external debt using standard financial indicators. Economic Trends and Economic Policy. Nr 97/2003.

Mladenović, Z., Nojković, A. 2008. Time series analysis: examples from the Serbian economy. Publishing Center of the Faculty of Economics in Belgrade. Beograd.

Neaime, S. 2015. Sustainability of budget deficits and public debts in selected European Union countries. The Journal of Economic Asymmetries 12: 1-21.

Novak, I. 2008. Analysis of external debt by the RH - model of multiple linear regression. Proceedings of the Faculty of Economics and Business in Zagreb. Vol.6. No.1. 2008. 157-178.

Reinhart, C. M. and Rogoff, K. S. 2010. Growth in a time of debt. American Economic Review 100 (2): 573-78.

Saint-Paul, G. 2012. Fiscal policy in an endogenous growth model. Review of Economic Studies 79 (2): 678-706.

Sims, C. A. 1980. Macroecomics and reality. Econometrica 49. 1-48.

Smith, A. 1776. An Inquiry into the Causes and Nature of the Wealth of Nations. 5.

Stiglitz, J. E. 2000. Economic of the Public Sector: Third Edition. W.W. Norton \& Company, New York and London.

Wilox, D. W. 1989. The Sustainability of Government Deficits: Implication of the Present Value Borrowing Constraint. Journal of Money. Credit and Banking. 21 291-306.

Zbinden, M., Dahinden, J. and Efendic, A. 2016. Diversity of migration in South-East Europe. Peter Lang, Bern. 